\title{
The Role of Village-owned Enterprises (BUMDes) in Optimizing Village Funds in South Lampung District
}

\author{
Alhamidi and Varida Henemia Pakpahan, ${ }^{1}$ \\ Sumatra Institute of Technology - Lampung Selatan - Indonesia \\ Hendro Muliarto \\ Ministry of Public Works and Public Housing Republic of Indonesia - Indonesia
}

\begin{abstract}
The purpose of this study is to see how to determine the BUMDes (Village-owned Enterprises) development strategy through optimizing the use of village funds in South Lampung District, Lampung Province. The study is conducted with interviews and questionnaires to the community in the village who would develop BUMDes. The methods used are descriptive analysis and SWOT. Some findings indicate that village-owned companies are needed to control the economy in the village.
\end{abstract}

Keywords: village funds; rural development; rural community; village-owned enterprise

\footnotetext{
${ }^{1}$ Alhamidi, Varida Henemia Pakpahan, Urban and Regional Planning, Sumatra Institute of Technology, Lampung, Indonesia, and Hendro Muliarto, Ministry of Public Works and Public Housing, Indonesia. Alhamidi013@gmail. com
} 


\section{Peran Badan Usaha Milik Desa (BUMDes) dalam Mengoptimalkan Pemanfaatan Dana Desa}

Alhamidi, Varida Henemia Pakpahan dan Hendro Muliarto

\section{Pendahuluan}

Perkembangan desa dan Kawasan pedesaan memiliki pengaruh yang besar dalam pembangunan daerah, pengurangan kesenjangan antarwilayah dan pengentasan kemiskinan. Pertumbuhan desa di Indonesia meningkat pesat mencapai 1.409 desa pertahun atau rata-rata pertumbuhan desa sebesar 2,29 persen. Sayangnya, peningkatan jumlah desa tidak diikuti dengan peningkatan kesejahteraan masyarakat desa. Berdasarkan data Ditjen PUM Kementerian Dalam Negeri, pada tahun 2017 terdapat 34 Provinsi, 514 kabupaten/kota, 7.145 Kecamatan dengan jumlah desa sebanyak 74.957 desa. Berdasarkan data dari Kementerian Desa, Pembangunan Daerah Tertinggal dan Transmigrasi terdapat 2.519 desa tertinggal dan 23,32 persen desa sangat tertinggal. Sangat rendahnya tingkat kesejahteraan masyarakat desa yang mengakibatkan perkembangan ekonomi Indonesia melemah. Sehingga saat ini pemerintah tengah berkonsentrasi dalam pembangunan dari desa atau Kawasan pinggiran untuk mengatasi permasalahan di desa dengan mengeluarkan beberapa regulasi yakni Undang-Undang Nomor 6 Tahun 2014 Tentang Desa dan alokasi dana desa yang ditambahkan untuk meningkatkan perekonomian di desa sehingga permasalahan yang selama ini dapat terselesaikan dan desa dapat mandiri.

Salah satu desa yang dapat dibilang cukup tertinggal tetapi memiliki potensi yang besar yaitu desa-desa di Kecamatan Jati Agung, Kabupaten Lampung Selatan seperti sumberdaya Alam, Sumberdaya Manusia, Sumberdaya Sosial, dan Sumberdaya Ekonomi Kreatif Masyarakat. Tetapi, dengan potensi yang besar tersebut, tidak dapat termanfaatkan secara optimal karena keterbatasan sumber pendanaan menyebabkan timbul beberapa permasalahan di desa-desa kecamatan Jati Agung. Permasalahan yang terjadi di desa-desa tersebut adalah masih minimnya sarana prasarana infrastruktur seperti jalan, masih terbatasnya modal usaha yang dimiliki masyarakat, masih rendahnya tingkat kesehatan masyarakat, belum tersusunnya program/rencana kegiatan dari desa, dan masih rendahnya kesadaran masyarakat dalam pemeliharaan lingkungan hidup. Dalam mengelola potensi dan meminimalkan permasalahan yang ada maka diperlukan suatu Lembaga yang dapat 
mengelola dan menghidupkan ekonomi masyarakat desa melalui Badan Usaha Milik Desa (BUMDes).

Eksistensi BUMDes saat ini ditengah-tengah masyarakat menjadikan suatu perhatian dimana masyarakat dapat menjalankan usaha dibidang ekonomi maupun pelayanan umum yang tidak hanya berorientasi pada keuntungan tetapi dapat berorientasi dalam mendukung peningkatan kesejahteraan masyarakat desa. BUMDes pun memiliki peran hampir sama dengan BUMN atau BUMD dimana dapat menjadi asset desa agar desa dapat memiliki pemasukan sendiri sehingga tidak tergantung pada sumber pendanaan dari pemerintah pusat. BUMDes juga dapat bersaing atau memasarkan produknya lintas desa bahkan antarregional sehingga meningkatkan jaringan pasar BUMDes itu sendiri. Menurut Harmiati, salah satu yang menjadi perhatian terhadap BUMDes melakukan perluasan pasar produk lokal harus mempertimbangkan beberapa hal berikut: 1) Membangun pusat pemasaran khusus dan outlet untuk produk-produk BUMDes; 2) Menyusun regulasi yang mewajibkan pasar modern untuk ikut memasarkan produk-produk BUMDes; dan 3) Menerapkan linkage strategy antara BUMDes penghasil bahan baku perantara dengan industri yang bergerak di sektor hilir (Soleh, 2017). Dari ketiga indikator perluasan pasar lokal dengan menerapkan linkage strategy antara BUMDes dengan BUMDes desa sekitarnya agar terjadi hilirisasi pergerakan produk antar BUMDes tidak saling tumpang tindih, maka diperlukan pengoptimalan Konsep BUMDes dalam optimalisasi sumber pendanaan dan pembiayaan pembangunan desa sehingga terwujudnya kemandirian dan ketahanan ekonomi desa.

\section{Tinjauan Pustaka}

\subsection{Desa}

Menurut Undang-Undang Nomor 6 Tahun 2014 Tentang Desa, Desa adalah kesatuan masyarakat hukum yang memiliki batas wilayah yang berwenang untuk mengatur dan mengurus urusan pemerintahan, kepentingan masyarakat setempat berdasarkan prakarsa masyarakat, hak asal usul, dan/atau hak tradisional yang diakui dan dihormati dalam sistem pemerintahan Negara Kesatuan Republik Indonesia. Dimana menurut Bappenas, desa diklasifikasikan menjadi 3 berdasarkan Indeks Pembangunan Desa, yaitu desa mandiri, desa berkembang dan desa tertinggal. Desa Mandiri adalah desa yang mempunyai ketersediaan dan akses terhadap pelayanan dasar yang mencukupi, infrastruktur yang memadai, aksesibilitas/transportasi yang 
tidak sulit, pelayanan umum yang bagus, serta penyelenggaraan pemerintahan yang sudah sangat baik. Lalu Desa Berkembang adalah desa yang mempunyai ketersediaan dan akses terhadap pelayanan dasar, infrastruktur, aksesibilitas/ transportasi, pelayanan umum dan penyelenggaraan pemerintahan yang cukup memadai. Kemudian Desa Tertinggal yaitu desa yang mempunyai ketersediaan dan akses terhadap pelayanan dasar, infrastruktur, aksesibilitas/transportasi, pelayanan umum dan penyelenggaraan pemerintahan yang masih minim (Barokah, et al. 2015).

\subsection{Strategi Desa Mandiri}

Untuk meningkatkan desa mandiri melalui pembangunan dan pemberdayaan bagi masyarakat desa harus terus dilakukan oleh pemerintah dan daerah sebagai pola pendampingan. Pendampingan terhadap masyarakat desa penting dilakukan sesuai dengan Peraturan Pemerintah Nomor 34 tahun 2014 tentang Desa pasal 28 ayat (1) menjelaskan bahwa pendampingan secara berjenjang harus terus dilakukan sesuai dengan kebutuhan. Pendampingan berjenjang artinya bahwa pendampingan dilakukan secara terus menerus sesuai dengan harapan yang diinginkan oleh masyarakat. Pendampingan terhadap pemberdayaan masyarakat dilakukan secara berjenjang dengan tetap memperhatikan aspek kemandirian masyarakat. Masyarakat yang mandiri mempunyai peran strategis dalam pembangunan desa yang berkelanjutan. Dari pemberdayaan masyarakat akan menghasilkan sumber daya yang potensial dan professional yang dapat dijadikan sebagai pondasi dasar dalam pembangunan desa yang berkelanjutan.

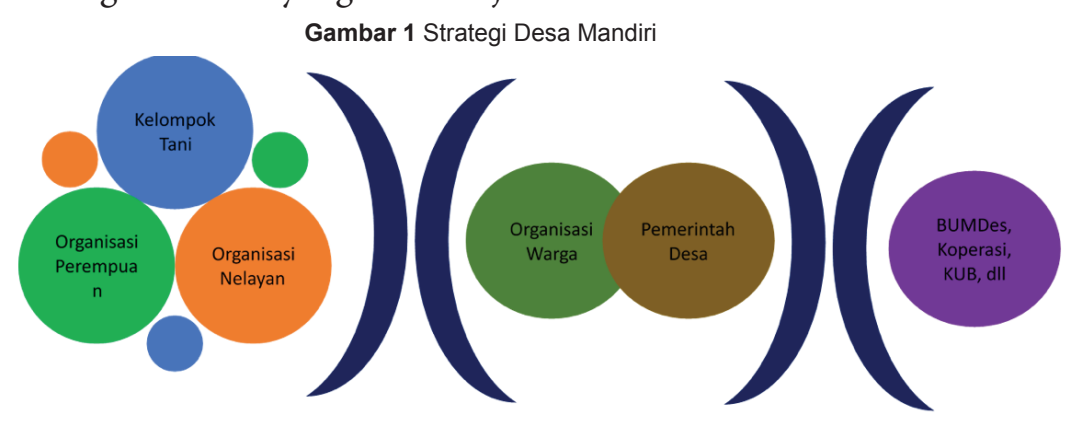

Sumber: Kurniawan, 2015

Ada beberapa strategi desa mandiri secara umum yang dapat diimplementasikan, yakni:

1. Membangun kapasitas warga dan organisasi masyarakat sipil di desa yang kritis dan dinamis melalui:

a) Assessment dan pemetaan kapasitas organisasi kemasyarakatan desa. 
b) Mengorganisasi dan menfasilitasi proses penguatan kapasitas kemasyarakat an desa melalui penyelenggaraan program/kegiatan yang berorientasi pada peningkatan kapasitas organisasi.

c) Pelibatan organisasi kemasyarakatan desa dalam proses-proses pengambil an kebijakan publik yang diselenggarakan pemerintah desa.

2. Memperkuat kapasitas pemerintahan dan interaksi dinamis antara organisasi warga dalam penyelenggaraan pemerintahan desa.

3. Membangun sistem perencanaan dan penganggaran desa yang responsif dan partisipatif.

\subsection{Badan Usaha Milik Desa}

Pengertian lain tentang BUMDes terdapat dalam Pasal 1 ayat (6) Peraturan Menteri Dalam Negeri Nomor 39 Tahun 2010 Tentang Badan Usaha Milik Desa, yang menyatakan bahwa BUMDes adalah usaha desa yang dibentuk/didirikan oleh pemerintah desa yang kepemilikan modal dan pengelolaannya dilakukan oleh pemerintah desa dan masyarakat. Selanjutnya BUMDes dalam Pasal 78 Peraturan Pemerintah Nomor 72 Tahun 2005 Tentang Desa dinyatakan bahwa dalam rangka meningkatkan pendapatan masyarakat dan desa, Pemerintah Desa mendirikan Badan Usaha Milik Desa (ayat 1) Pembentukan Badan Usaha Milik Desa ditetapkan dalam Peratuan Desa dengan berpedoman pada peraturan perundang-undangan (ayat 2). Bentuk Badan Usaha Milik Desa harus berbadan hukum (ayat 3). Badan Usaha Milik Desa (BUMDes) adalah lembaga usaha desa yang dikelola oleh masyarakat dan pemerintahan desa dalam upaya memperkuat perekonomian desa dan dibentuk berdasarkan kebutuhan dan potensi desa. Sebagai salah satu lembaga ekonomi yang beroperasi dipedesaan, BUMDes harus memiliki perbedaan dengan lembaga ekonomi pada umumnya. Ini dimaksudkan agar keberadaan dan kinerja BUMDes mampu memberikan kontribusi yang signifikan terhadap peningkatan kesejahteraan warga desa. Disamping itu, supaya tidak berkembang sistem usaha kapitalistis di pedesaan yang dapat mengakibatkan terganggunya nilai-nilai kehidupan bermasyarakat.

Menurut Undang-Undang Nomor 6 Tahun 2014, BUMDes adalah badan usaha yang seluruh atau sebagian besar modalnya dimiliki oleh Desa melalui penyertaan secara langsung yang berasal dari kekayaan Desa yang dipisahkan guna mengelola aset, jasa pelayanan, dan usaha lainnya untuk sebesar-besarnya 
kesejahteraan masyarakat Desa. BUMDes merupakan elemen dan instrument penggerak ekonomi masyarakat desa. BUMDes harus dipahami dan dilakukan secara maksimal. BUMDes menjadi pusat perekonomian masyarakat desa untuk menumbuhkembangkan ekonomi lokal. Keberadaan BUMDes adalah untuk memperkuat ekonomi rakyat desa (Sutoro dkk 2015). BUMDes dirancang untuk meningkatkan ekonomi desa dan kesejahteraan bagi masyarakat desa. BUMDes sebagai lumbung ekonomi desa harus dilakukan secara integrasi antara pemerintah pusat, pemerintah desa dan masyarakat desa. BUMDes bisa saja menjadi sentral ekonomi pedesaan, sehingga dapat menghasilkan produk unggulan desa yang dapat dipasarkan ke dunia international sebagai badan usaha yang seluruh atau sebagian besar modalnya dimiliki oleh Desa melalui penyertaan secara langsung yang berasal dari kekayaan desa yang dipisahkan guna mengelola aset, jasa pelayanan, dan usaha lain untuk sebesar-besarnya kesejahteraan masyarakat Desa (Sulistyoningsih 2015).

\section{Metodologi Penelitian}

Adapun jenis penelitian ini adalah penelitian kuantitatif deskriptif dan SWOT. Penelitian deskriptif dalam hal ini adalah untuk mengidentifikasi lingkungan internal dan eksternal Desa sehingga dapat menemukan dampak adanya kebijakan Badan Usaha Milik Desa (BUMDes) bagi masyarakat desa. Penelitian ini dilakukan di Kecamatan Jati Agung, Kabupaten Lampung Selatan. Metode pengumpulan data yang digunakan adalah metode primer dan metode sekunder, dimana data yang digunakan bersumber dari data-data wawancara dan kuesioner kepada masyarakat dan instansi terkait. Metode analisis yang digunakan yakni analisis deskriptif dan SWOT.

\section{Hasil dan Pembahasan}

\subsection{Gambaran Umum Wilayah Penelitian}

Pada penelitian ini, yang menjadi ruang lingkup studi wilayah terdiri dari 8 desa yang berada di Kecamatan Jati Agung, Kabupaten Lampung Selatan Provinsi Lampung. Desa-desa tersebut diantaranya adalah Desa Way Hui, Desa Jati Mulyo, Desa Karang Sari, Desa Karang Anyar, Desa Margakaya, Desa Marga Agung, Desa Margo Dadi dan Desa Margo Lestari. Desa Way Hui, Jati Mulyo, Karang Sari, Karang Anyar, Marga Kaya, Marga Agung, Margo Dadi dan Desa Margo Lestari merupakan beberapa desa yang berada di Kecamatan Jati Agung Kabupaten Lampung Selatan 
yang memiliki luas wilayah yang beragam dengan batas wilayah yang berbeda juga.

Tabel 1. Luas Wilayah Desa dan Batas Wilayah Geografis Desa

\begin{tabular}{|c|c|c|c|c|c|}
\hline \multirow[t]{2}{*}{ Nama Desa } & \multirow{2}{*}{$\begin{array}{c}\text { Luas } \\
\text { Wilayah } \\
\left(\mathrm{km}^{2}\right)\end{array}$} & \multicolumn{4}{|c|}{ Batas Wilayah } \\
\hline & & Utara & Selatan & Barat & Timur \\
\hline Way Huwi & 4,93 & Jatimulyo & Harapan Jaya & Way Kandis & PTP Way Galih \\
\hline Jatimulyo & 10,59 & $\begin{array}{c}\text { Karang Sari and } \\
\text { Marga Agung }\end{array}$ & Way Huwi & $\begin{array}{l}\text { Fajar Baru and } \\
\text { Karang Sari }\end{array}$ & Banjar Agung \\
\hline Margodadi & 6,48 & Sumber Jaya & Gedung Harapan & Margo Lestari & Gedung Agung \\
\hline Margo Lestari & 6,25 & Karang Rejo & Gedung Harapan & Marga Agung & Margodadi \\
\hline Marga Agung & 5,76 & Marga Kaya & Jati Mulyo & Karang Anyar & Margo Lestari \\
\hline Marga Kaya & 7,15 & Karang Anyar & Marga Agung & Karang Anyar & $\begin{array}{c}\text { Rejo Mulyo and PTIP TRI } \\
\text { KORA }\end{array}$ \\
\hline Karang Anyar & 10,75 & Rejo Mulyo & Karang Sari & Krawang Sari & Marga Kaya \\
\hline Karang Sari & 7,25 & Karang Anyar & Fajar Baru & Fajar Baru & Jatimulyo and Marga Agung \\
\hline
\end{tabular}

Sumber: Jati Agung Dalam Angka 2017 dan Profil Desa 2017

Dari segi demografi, Kecamatan Jati Agung mengalami peningkatan jumlah penduduk termasuk di dalamnya 8 desa yang menjadi wilayah penelitian. Pada tahun 2016, dari ke-8 desa, jumlah penduduk yang paling banyak adalah Desa Jatimulyo dengan jumlah 16,942 jiwa, diikuti oleh jumlah penduduk di Desa Karang Anyar sebanyak 16,069 jiwa, sedangkan jumlah penduduk yang paling rendah diantara ke-8 desa adalah Desa Margo Lestari yang hanya memiliki jumlah penduduk sebesar 2,747 jiwa.

Table 2. Banyaknya Penduduk menurut Jenis Kelamin dan Sex Ratio Tahun 2016

\begin{tabular}{|l|c|c|c|c|c|}
\hline \multirow{2}{*}{ Nama Desa } & \multicolumn{3}{|c|}{ Penduduk } & \multirow{2}{*}{ Sex Ratio } & \multirow{2}{*}{ KK } \\
\cline { 2 - 4 } & Laki-laki & Perempuan & Jumlah & & \\
\hline 1. Way Huwi & 7,422 & 6,506 & 13,928 & 1.14 & 3,482 \\
\hline 2. Jatimulyo & 8,711 & 8,231 & 16,942 & 1.06 & 4,236 \\
\hline 3. Margodadi & 1,416 & 1,345 & 2,761 & 1.05 & 690 \\
\hline 4. Margo Lestari & 1,451 & 1,296 & 2,747 & 1.12 & 687 \\
\hline 5. Marga Agung & 2,117 & 2,132 & 4,249 & 0.99 & 1,062 \\
\hline 6. Marga Kaya & 1,677 & 1,563 & 3,240 & 1.07 & 810 \\
\hline 7. Karang Anyar & 8,249 & 7,820 & 16,069 & 1.05 & 4,017 \\
\hline 8. Karang Sari & 2,249 & 2,160 & 4,409 & 1.04 & 1,102 \\
\hline
\end{tabular}

Sumber: Jati Agung Dalam Angka 2017

Selain itu, kegiatan ekonomi di desa tersebut terdapat fasilitas sarana perdagangan yakni pasar tradisional, took, restoran, warung kelontongan, mini market, fotocopy, studio foto, salon kecantikan/rias pengantin, dan sebagainya. Untuk pasar tradisional terdapat pada desa Jatimulyo, Margodadi, Margo Agung, 
dan Karang Anyar. Tidak hanya sarana perdagangan, terdapat juga fasilitas Lembaga keuangan seperti Bank pada desa Jatimulyo dan Karang Anyar, Koperasi lainnya juga terdapat pada desa Jatimulyo, Margodadi, Marga Kaya dan Karang Anyar..

\subsection{Alokasi Dana Desa}

Alokasi dana desa atau transfer dari pemerintah pusat ke daerah setiap tahunnya terus meningkat dari tahun 2015 sampai tahun 2018 saat ini. Peningkatan yang sangat signifikan terjadi dari tahun 2015 ke tahun 2016 sebesar duakali lipat dari alokasi dana desa sebelumnya. ini menunjukkan bahwa pemerintah sedang melakukan reformasi pembiayaan pembangunan daerah dalam memperbaiki tingkat kesejahteraan masyarakat desa yang jauh dari kata sejahtera. Ditambah dengan rendahnya tingkat infrastruktur dasar yang tersedia di desa, mengakibatkan desa semakin buruk. Alokasi dana desa sebagai salah satu sumber pendanaan pembangunan daerah/desa memiliki prioritas penggunaan dana desa untuk pembangunan desa yaitu meningkatkan kesejahteraan masyarakat desa dan kualitas hidup manusia serta penanggulangan kemiskinan dengan cara a) pemenuhan kebutuhan dasar, b) pembangunan sarana dan prasarana desa, c) pengembangan potensi ekonomi desa, dan d) pemanfaatan sumber daya alam dan lingkungan secara berkelanjutan. Berikut alokasi dana desa dari tahun 2015-2018.

Table 3. Besaran Alokasi Dana Desa (ADD) di Desa Wilayah Penelitian Tahun 2015-2018

\begin{tabular}{|l|c|c|c|c|}
\hline \multirow{2}{*}{\multicolumn{1}{|c}{ Desa }} & \multicolumn{4}{|c|}{ Alokasi Dana Desa (Rp ribu) } \\
\cline { 2 - 5 } & 2015 & 2016 & 2017 & 2018 \\
\hline 1. Way Huwi & 303.747 & 681.764 & 868.118 & 950.370 \\
\hline 2. Jatimulyo & 325.040 & 729.557 & 928.974 & 1.016 .993 \\
\hline 3. Margodadi & 280.405 & 629.373 & 801.406 & 877.337 \\
\hline 4. Margo Lestari & 280.210 & 628.934 & 800.848 & 876.726 \\
\hline 5. Marga Agung & 282.330 & 633.692 & 806.906 & 883.358 \\
\hline 6. Marga Kaya & 279.746 & 627.893 & 799.521 & 875.274 \\
\hline 7. Karang Anyar & 334.660 & 751.149 & 956.468 & 1.047 .091 \\
\hline 8. Karang Sari & 290.271 & 651.517 & 829.603 & 908.206 \\
\hline
\end{tabular}

Sumber: Peraturan Bupati Lampung Selatan 2015-2018

Eksisting alokasi dana desa (ADD) yang ditransfer ke desa terserap 100\% dengan dimanfaatkan sebagian besar untuk pembangunan infrastruktur, 30\% alokasi dana desa untuk pemberdayaan masyarakat, Badan Usaha Milik Desa sebesar 10\% dari alokasi dana desa sebagai pendukung kegiatan ekonomi baik yang dikembangkan oleh BUMDes dan kelompok usaha masyarakat desa yakni karang taruna dan 
kelompok wanita tani, dan sisanya untuk peningkatan kualitas proses perencanaan desa di desa-desa tersebut. Dengan sebesar 40\% dari alokasi dana desa untuk sektor penggerak ekonomi yakni pemberdayaan masyarakat dan BUMDes menimbulkan terserapnya tenaga kerja dalam pelaksanaan terutama pemberdayaan masyarakat melalui kelompok wanita tani dan karang taruna serta BUMDes melakukan suatu kegiatan membuat warung desa sebagai market/asset desa dalam menggerakkan perekonomian masyarakat desa.

\subsection{Kegiatan Ekonomi Desa}

Dengan adanya alokasi dana desa (ADD) kegiatan ekonomi desa mengalami pergerakan kearah positif meningkatkan kesejahteraan/pendapatan masyarakat desa akibat adanya pemberdayaan masyarakat. Trend pertumbuhan ekonomi kreatif di desa menjadi sangat tinggi, ditandai dengan banyak produk-produk hasil dari desa yang menjadi ciri khas desa tersebut mengakibatkan pertambahan nilai produk dan dikemas dengan kreativitas. Produk-produk tersebut dijual di dalam desa dan diluar desa, sehingga menjadi salah satu pemasukan desa/pendapatan masyarakat desa. Produk-produk hasil masyarakat desa, yaitu keripik pisang, keripik singkong, anyaman sangkek, hasil pertanian (padi), sembako, gria antik bambu, kerajinan tangan sulam usus, kerupuk, tempe, dan daur ulang sampah. Saat ini, kegiatan produk diatas masih skala rumah tangga belum ada Lembaga sebagai pengelola/ pengumpul agar produk-produk tersebut dipasarkan dan memiliki nilai tambah yang besar serta dapat dilakukan ekspansi ke luar desa dengan produksi yang besarbesaran dan harga yang relatif murah dipasarkan di warung milik BUMDes terpadu.

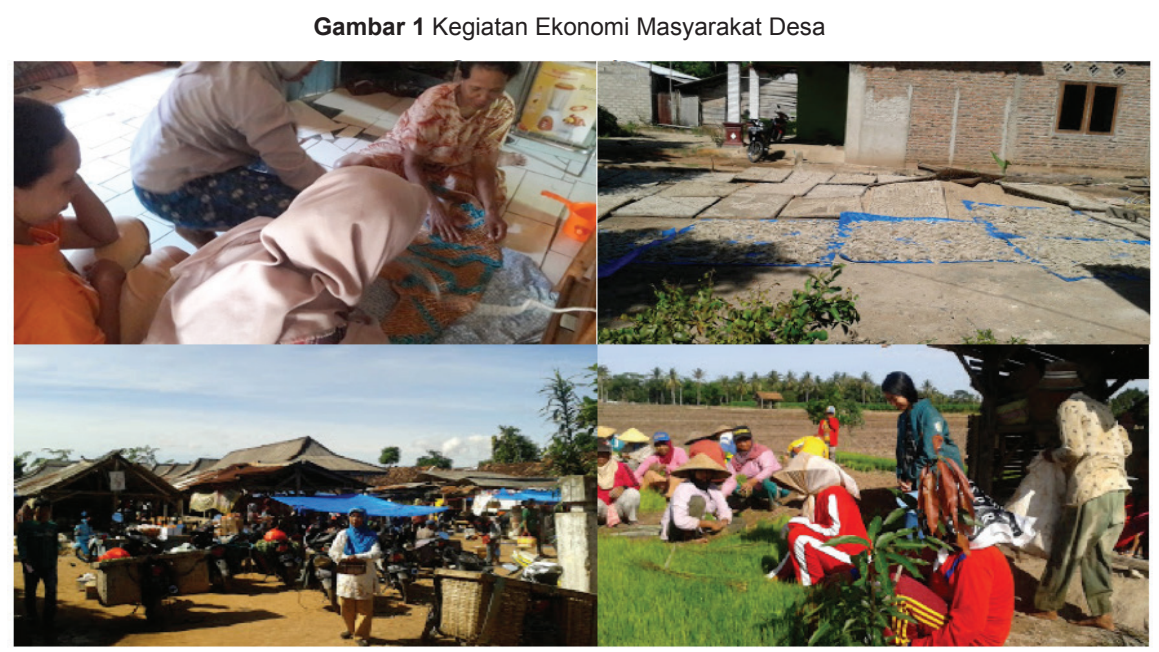




\subsection{Hambatan, dan Peluang Desa Dalam Ketahanan dan Kemandirian Ekonomi}

Dalam pelaksanaan pasti memiliki kekuatan, kelemahan secara internal dan peluang dan hambatan secara eksteranal untuk mencapai ketahanan dan kemandirian ekonomi desa melalui pengoptimalan manfaat dari sumber pendanaan desa. Kekuatan yang dimilik desa-desa dalam lingkup penelitian, yaitu:

1. Memiliki jumlah penduduk dan angkatan kerja yang relatif banyak besar;

2. Memiliki lahan pertanian yang masih cukup luas;

3. Terjalinnya hubungan yang sinergis antara pemerintah dan lembaga pemberdayaan masyarakat yang ada;

4. Memiliki sarana perkantoran dan olahraga;

5. Partisipasi masyarakat dalam pembangunan yang cukup besar;

6. Adanya komitmen kuat dari pemerintah desa untuk melakukan perubahan;

7. Masyarakat yang kreatif dan inovatif yang tinggi/ekonomi kreatif.

Kemudian yang menjadi unsur kelemahan yang dimiliki oleh desa-desa dalam lingkup penelitian adalah sebagai berikut:

1. Masih cukup tingginya angka kemiskinan (warga miskin);

2. Lemahnya profesionalisme perangkat desa;

3. Terbatasnya kemampuan keuangan desa;

4. Belum optimalnya pengelolaan tanah kas desa sebagai sumber pendapatan;

5. Kualitas sarana dan prasarana umum yang umumnya rendah seperti infrastruktur jalan dan pertanian;

6. Daya dukung lingkungan yang semakin turun oleh karena adanya limbah dan sampah yang belum terkelola.

Setelah itu, unsur peluang yang dimiliki oleh desa-desa dalam lingkup penelitian antara lain:

1. Undang-Undang Nomor 23 Tahun 2014 tentang Pemerintah Daerah;

2. Sistem perencanaan nasional dan daerah dengan sistem bottom up;

3. Adanya tawaran pihak ke tiga (swasta) dalam rangka investasi;

4. Adanya Institut Teknologi Sumatera sebagai kawasan pendidikan tinggi, pusat penelitian dan tujuan wisata;

5. Adanya pintu tol trans Sumatera Kota Baru-Bandar Lampung yang meningkatkan aksesibilitas transportasi.

Kemudian yang merupakan unsur hambatan yang dimiliki oleh desa-desa dalam lingkup penelitian adalah sebagai berikut: 
1. Segregasi yang masih terasa sebagai dampak kritis multidimensisal yang berkepanjangan;

2. Belum optimalnya koordinasi horizontal antarwilayah sehingga membutuhkan waktu yang lama;

3. Persaingan kebijakan pengembangan wilayah dengan desa lain di wilayah Kecamatan Jati Agung;

4. Letak geografis Desa yang berbatasan dengan kota Bandar Lampung sebagai PKN.

Dengan menggunakan analisis SWOT, maka pemerintah desa dapat menguraikan secara terperinci, mengenai permasalahan, peluang, kelebihan, kekurangan yang ada di Desanya dengan tujuan untuk menentukan formulasi yang sesuai dengan mengacu pada analisis SWOT tersebut, sehingga kebijakan yang digagas dapat terimplementasikan secara tepat atau sesuai sasaran dan bermanfaat. Terutama pada ekternal yakni peluang dan hambatan dalam mencapai ketahanan dan kemandirian ekonomi desa itu sendiri sebagai berikut.

\begin{tabular}{|c|l|l|}
\hline SWOT & \multicolumn{1}{|c|}{ Strength } & \multicolumn{1}{c|}{ Weakness } \\
\hline \multirow{3}{*}{ Opportunity } & $\begin{array}{l}\text { Pemerintah membuat kebijakan yang } \\
\text { memaksimalkan Sumberdaya Alam } \\
\text { dan Sumberdaya Manusia mengfungsi } \\
\text { BUMDes dengan pemberdayaan } \\
\text { masyarakat melalui dana desa }\end{array}$ & $\begin{array}{l}\text { Melakukan Pelatihan masyarakat miskin melalui } \\
\text { pengefisienan anggaran belanja desa dan menjalin ker- } \\
\text { jasama dengan swasta melalui BUMDes }\end{array}$ \\
\hline \multirow{3}{*}{ Threats } & $\begin{array}{l}\text { Produk-Produk hasil masyarakat desa } \\
\text { melalui BUMDes melakukan penge- } \\
\text { lolaan dan meningkatkan kerjasama } \\
\text { antar BUMDes desa lain sehingga } \\
\text { produk dapat diekspor ke wilayah desa } \\
\text { lain dan Kota Bandar Lampung }\end{array}$ & $\begin{array}{l}\text { Pemerintah desa belum sadar akan potensi yang dimi- } \\
\text { liki desanya sehingga potensi tersebut belum termasi- } \\
\text { malkan dan masyarakat memanfaatkan tersebut bersi- } \\
\text { fat skala rumah tangga }\end{array}$ \\
\hline
\end{tabular}

Sumber: Hasil Analisis, 2018

\subsection{Strategi Pengembangan BUMDes Sebagai Ketahanan dan Kemandirian Ekonomi}

Konsep pengembangan BUMDes pada wilayah studi dengan memperhatikan karakteristik Kawasan dan komoditas unggulan/produk-produk hasil masyarakat diterapkan konsep central place theory (Christaller). Dimana konsep tersebut membentuk pusat-pusat pelayanan strategis dan sub pusat pelayanan serta pusat lingkungan yang dapat melayani diri sendiri. Konsep ini, dinilai cukup efektif dimana komoditas unggulan dari wilayah tersebut relative homogen/sama, yang membedakan yakni pada jumlah pangsa pasar dan kemudahan aksesibiltas menuju Kawasan ekonomi tersebut. Sehingga komoditas yang supplynya besar menjadi pusat/pasar tempat masyarakat membeli barang tersebut yang dikelola oleh BUMDes 
dan pusat-pusat tersebut akan dikembangkan hanya pada komoditas basis/unggulan saja. Oleh sebab itu, dapat menerapkan konsep central place theory antar BUMDes desa melakukan kerjasama horizontal dan dapat melakukan finance sharing antar BUMDes.

Strategi pengembangan BUMDes dengan menggunakan konsep tersebut yakni pada BUMDes yang menjadi pusat pelayanan menjadi pusat pasar/komoditas dimana komoditas yang ada disupply dari BUMDes-BUMDes sekitarnya (BUMDes Sub Pusat Pelayanan), sedangkan BUMDes Sub Pusat Pelayanan sebagian besar disupplay dari BUMDes Pusat Lingkungan sebagai market. Dan terus berputar saling menyupply komoditas/produk hasil desa BUMDes tersebut sehingga terjadi perputaran perekonomian dan dapat menarik investasi dan berdampak pada ketahanan dan kemandirian ekonomi desa. Setelah terpenuhinya kebutuhan masyarakat, produk/komoditas akan di ekspor keluar wilayah BUMDes sehingga mengakibatkan peningkatan ekonomi dimana pemasukan desa akan mengalami peningkatan yang signifikan dan tenaga kerja yang terlibat seluruh masyarakat desa. Jadi, Strategi pengembangan usaha milik desa untuk menggunakan konsep Central Place Theory yang setiap desa harus bekerja sama satu sama lain, terhubung, transparan dan terintegrasi untuk mengelola ekonomi di desa. Sehingga uang yang dihasilkan masyarakat terus berputar di desa-desa yang dicakup oleh perusahaanperusahaan milik desa. Selain itu, orang dapat menjual produknya ke BUMDes, kemudian BUMDes mengelola dan menjualnya kembali ke desa dalam ruang lingkupnya serta di luar lingkup BUMDes.

Gambar 3 Strategi Pengembangan BUMDes

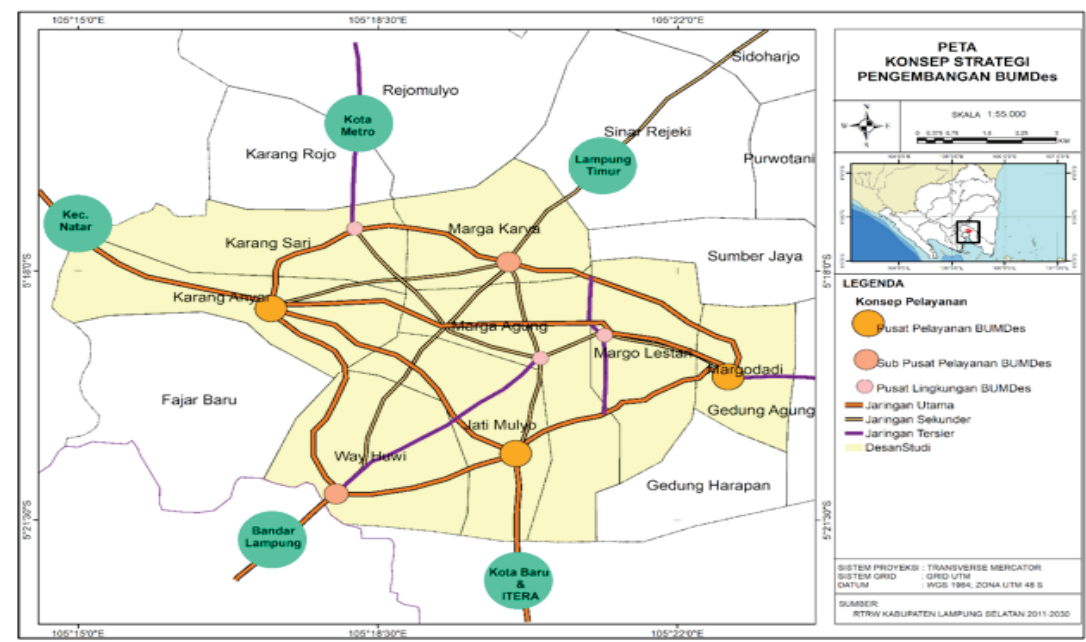

Sumber: Hasil Analisis, 2018 


\section{Kesimpulan dan Saran}

Berdasarkan hasil analisis diatas dapat disimpulkan bahwa dengan adanya alokasi dana desa sangat memiliki dampak yang sangat signifikan terhadap kesejahteraan masyarakat desa melalui beberapa program pemanfaatan dan pengoptimalan sumber pendanaan tersebut yakni Badan Usaha Milik Desa dan Pemberdayaan Masyarakat sebesar 40\% dari alokasi dana desa. Walaupun terdapat hambatan dalam pengembangan ekonomi desa, tetapi masih dapat memanfaatkan peluang untuk memperkecil hambatan tersebut dengan mengoptimalkan sumber pendanaan tersebut dapat melalui kegiatan ekonomi desa dan konsep Central Place Theory dalam pengembangan BUMDes.

Untuk memperbaiki kekurangan penelitian yang telah dilakukan dan memaksimalkan pada penelitian selanjutnya, dapat diberikan saran-saran sebagai berikut.

- Memperluas daerah cakupan penelitian, sehingga menghasilkan hasil yang lebih representatif dan komprehensif dalam melakukan penerapan konsep BUMDes.

- Memperdalam analisis untuk tiap aspek sehingga dapat dilihat tingkat perilaku masyarakat desa.

- Perlu adanya kajian terkait penggunaan/perencanaan APD Desa secara mendetail agar pembiayaan sesuai dengan dibutuhkan oleh masyarakat desa dan perlu pendampingan terhadap desa-desa dalam mengelola dana desa.

\section{References}

Barokah, H., Utami, D. R., Karmaji, Sugiarto, C. S., Suchaini, U., Widyaningsih, D., . . . Abduh, M. (2015). Indeks Pembangunan Desa 2014 "Tantangan Pemenuhan Standar Pelayanan Minumum Desa”. Jakarta: Kementerian PPN/Bappenas.

Hamidi, H., Setijonegoro, N., Fujitriartanto, Sa'id, A., Harioso, Huda, . . Mu'arofah, A. F. (2015). Indeks Desa Membangun 2015. Jakarta: Kementerian Desa, Pembangunan Daerah Tertinggal dan Transmigrasi.

Kurniawan, B. (2015). Desa Mandiri, Desa Membangun. Jakarta: Kementerian Desa, Pembangunan Daerah Tertinggal dan Transmigrasi.

Selatan, B. L. (2015). Peraturan Bupati Lampung Selatan No. 251 Tahun 2015 Tentang Tata Cara Pembagian dan Penetapan Rincian Dana Desa Di Kabupaten Lampung Selatan. Kalianda: Pemerintah Kabupaten Lampung Selatan.

Soleh, A. (2017). Strategi Pengembangan Potensi Desa. Jurnal Sungkai, 32-52.

Sulistyoningsih, E. D. (2015). Push Factor Partisipasi dan Pemberdayaan Perempuan Dalam Pengembangan Badan Usaha Milik Pedesaan (BUMDes) Studi Kusus Faktor Pendorong Partisipasi Perempuan Dalam Upaya Membangun BUMDes Di Desa Serang Kecamatan Karangreja Kab. Purbalingga. Semnasbahtera, 244-260. 
Sutoro, E., \& dkk. (2015). Modul Pelatihan Pratugas Pendampingan Desa: Implementasi Undang-Undang Desa Nomor 6 Tahun 2014 Tentang Desa. Jakarta: Kementerian Desa, Pembangunan Daerah Tertinggal dan Transmigrasi.

Undang-Undang Nomor 6 Tahun 2014 tentang Desa.

Zulkarnaen, R. M. (2016). Pengembangan Potensi Ekonomi Desa Melalui Badan Usaha Milik Desa Pondok Salam Kabupaten Purwakarta. Jurnal Aplikasi Ipteks untuk Masyarakat, 1-4. 